Russian Academy of Sciences

Far Eastern Branch

Botanical Garden-Institute

Institute of Biology and Soil Science

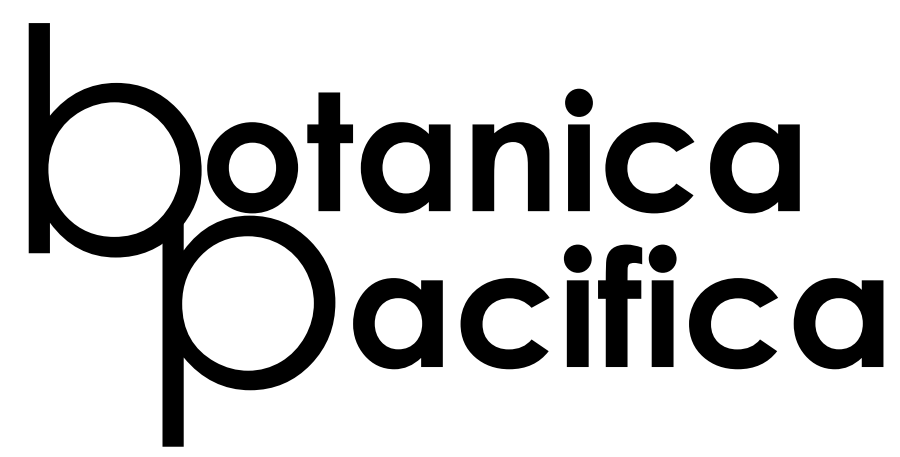

A JOURNAL OF PLANT SCIENCE
AND CONSERVATION

VOlUME 2, NO. 12013 
Botanica Pacifica

A JOURNAL OF PLANT SCIENCE AND CONSERVATION

VOLUME 2, NO. 12013
Botanica Pacifica (BP) publishes peer-reviewed, significant research of interest to a wide audience of plant versity, genetics, evolution, systematics), organization (molecular to ecosystem), and all plant groups and allied organisms (cyanobacteria, fungi, and lichens). Indexed by Russian Science Citation Index (http://elibrary.ru/title_about. asp?id $=34460$ ) scientists in all areas of plant biology (structure, function, development, di-
Botanica Pacifica (BP) пуболикует результаты исследований, прошедших независимую экспертизу и преАставАяющих значительный интерес широкому кругу ботаников во всех областях науки о растениях (структура, функции, развитие, разнообразие, генетика, эволюция и систематика), на всех уровнях организации живого (от молекулярного Ао экосистемного), по всем группам растений и родственным организмам (цианобактерии, грибы и кишайники). Индексируется Российским индексом научного цитирования (http://elibrary.ru/title_about. asp?id $=34460)$

\section{Chief editors:}

Pavel V. KRESTOV - Botanical Garden-Institute FEB RAS, Vladivostok, Russia

Peter G. GOROVOI - Pacific Institute of Bio-Organic Chemistry FEB RAS, Vladivostok, Russia

Vadim A. BAKALIN - Botanical Garden-Institute FEB RAS, Vladivostok, Russia

\section{Editorial board:}

Zumabeka AZBUKINA - Institute of Biology and Soil Science FEB RAS, Vladivostok, Russia Vyacheslav Yu. BARKALOV - Institute of Biology and Soil Science FEB RAS, Vladivostok, Russia Nadezhda I. BLOKHINA - Institute of Biology and Soil Science FEB RAS, Vladivostok, Russia Dmitrii E. KISLOV - Botanical Garden-Institute FEB RAS, Vladivostok, Russia

Andrei E. KOZHEVNIKOV - Institute of Biology and Soil Science FEB RAS, Vladivostok, Russia Yuri I. MANKO - Institute of Biology and Soil Science FEB RAS, Vladivostok, Russia Alexander M. OMELKO - Institute of Biology and Soil Science FEB RAS, Vladivostok, Russia Boris S. PETROPAVLOVSKII - Botanical Garden-Institute FEB RAS, Vladivostok, Russia Nina S. PROBATOVA - Institute of Biology and Soil Science FEB RAS, Vladivostok, Russia Larisa N. VASILYEVA - Institute of Biology and Soil Science FEB RAS, Vladivostok, Russia Yurii N. ZHURAVLEV - Institute of Biology and Soil Science FEB RAS, Vladivostok, Russia

\section{Editorial council:}

Konstantin S. BAIKOV - Institute of Soil Science and Agrochemistry SB RAS, Novosibirsk, Russia Elgene O. BOX - University of Georgia, Athens, USA

Victor V. CHEPINOGA - Irkutsk State University, Irkutsk, Russia

Klaus DIERSSEN - University of Kiel, Kiel, Germany

Nicolai B. ERMAKOV - Central Siberian Botanical Garden SB RAS, Novosibirsk, Russia

Andrew N. GILLISON - Center for Biodiversity Management, Yungaburra, Australia

Andrew M. GRELLER - Queens College, The City University of New York, New York, USA

Michael S. IGNATOV - Main Botanical Garden RAS, Moscow, Russia

Woo-Seok KONG - KyungHee University, Seoul, Republic of Korea

Nadezhda A. KONSTANTINOVA - Polar-Alpine Botanical Garden-Institute KSC RAS, Kirovsk, Russia Ilya B. KUCHEROV - Institute of Botany RAS, Saint-Petersburg, Russia

Victor Ya. KUZEVANOV - Botanical Garden of Irkutsk State University, Irkutsk, Russia

Yukito NAKAMURA - Tokyo University of Agriculture, Tokyo, Japan

Vladimir G. ONIPCHENKO - Moscow State University, Moscow, Russia

Dmitrii D. SOKOLOFF - Moscow State University, Moscow, Russia

Byung-Yun SUN - Chongbuk National University, Jeonju, Rep. Korea

Hideki TAKAHASHI - The Hokkaido University Museum, Hokkaido University, Sapporo, Japan Stephen S. TALBOT - US Fish and Wildlife Service, Anchorage, USA

Gennadii P. URBANAVICHUS - Institute of the Industrial Ecology Problems of the North KSC RAS, Apatity, Russia Pavel Y. ZHMYLEV - Moscow State University, Moscow, Russia

\section{Secretariat:}

Valentina A. KALINKINA - Botanical Garden-Institute FEB RAS, Vladivostok, Russia Eugenia V. BIBCHENKO - Botanical Garden-Institute FEB RAS, Vladivostok, Russia
(C) Botanica Pacifica 2012-2013. All rights reserved. No part of this publication may be reproduced, stored in a retrieval system or transmitted in any form or by any means without the written permission of the copyright holder. Requests for permission must be addressed to the editor.

C Botanica Pacifica 2012-2013. Bсе права защищены. Ни одна часть Аанного издания не может быть воспроизведена или передана в Аюбой форме и Аюббыми средствами (эмектронными, фотографическими или механическими), или представлена в поисковых системах без письменного разрешения держателя авторских прав, за которым следует обращаться к реАактору.

Издание зарегистрировано Федеральной службой по наАзору в сфере связи, информационных технологий и массовых коммуникаций Министерства связи и массовых коммуникаций Российской Федерации за № ПИ № ФС 77-52771

Journal Secretariat:

Botanica Pacifica

Botanical Garden-Institute FEB RAS

Makovskii Str. 142

Vladivostok 690024 RUSSIA

http://www.geobotanica.ru/bp

botanica.pacifica@icloud.com krestov@biosoil.ru v_bak@list.ru 


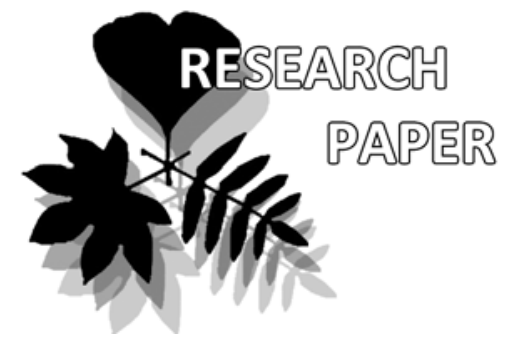

\title{
Hepatics of Mt. Deogyu National Park, Republic of Korea
}

\author{
Seung Se Chol ${ }^{1}$, Vadim A. Bakalin ${ }^{2,3}$ \& Byung-Yun Sun ${ }^{1}$
}

Seung Se Choi ${ }^{1}$

hepaticae@jbnu.ac.kr

Vadim A. Bakalin 2,3,*

v_bak@list.ru

Byung-Yun Sun ${ }^{1}$

sunby@jbnu.ac.kr

${ }^{1}$ Department of Life Sciences

Chonbuk National University

Jeonju 561-756 Republic of Korea

${ }^{2}$ Botanical Garden-Institute FEB RAS

Vladivostok 690024 Russia

${ }^{3}$ Institute of Biology \& Soil Science FEB RAS

Vladivostok 690022 Russia

* corresponding author

Manuscript received: 04.04.2013

Review completed: 25.04 .2013

Accepted for publication: 28.04.2013

\begin{abstract}
A B S T R A C T
We investigated the hepatic flora of Mt. Deogyu National Park in the Republic of Korea. We assembled a checklist including 127 taxa belonging to 28 families, 57 genera, 120 species, 4 subspecies, and 3 varieties. Seven species in the list are new for the country. We provide a description of the study area, a history of hepatic exploration on the Korean Peninsula, and details of altitudinal distribution patterns in the park.
\end{abstract}

Keywords

Hepaticae, liverworts, Marchantiophyta, Mt. Deogyu, South Korea

\section{P E 3 Ю M E}

Чои С.С., Бакалин В.А., Сан Б.-Ю.

Печеночники национального парка Гора Аеогу, Республика Корея

Изучена флора печеночников национального парка г. Аогю (республика Корея). Составленный список включает 127 таксонов из 28 семейств, 57 родов, 120 виАов, 4 подвиАОв и 3 разновиАностей. Семь виАОв приводится впервые Аля республики Корея. Ааны комментарии о высотно-поясном распределении печеночников, описаны район исследования и история исследования печеночников Корейского п-ова.

Ключевые слова

Hepaticae, печеночники, Marchantiophyta, Южная Корея

\section{N T ROD UCTION}

Faurie (1847-1915) was the first to collect hepatics on the Korean Peninsula. In collaboration with Taquet, he sampled diverse hepatics and mosses while amassing a large collection of vascular plants. The collections were studied by Stephani (1909-1912, 1912-1917, 1917-1924, 1924) and listed in his well-known Species Hepaticarum. Six species from the collection were described by Stephani as new to science (Hong 1966). Since then, Korean Hepaticae have been studied mostly by Japanese botanists, including Nakai (1918), Reimers (1931), Horikawa (1932, 1934, 1955), Hattori (1943, 1947, 1952, 1956, 1978), Hattori et al. (1962a, 1962b), Ando (1955, 1960), Amakawa (1960), and Inoue (1958a, 1958b, 1959a, 1959b, 1962).

The first Korean botanist to study hepatics of the Republic of Korea was Hong (1960a, 1960b, 1960c, 1966, 1997, 2003). He reported 135 taxa in 41 genera and 18 families, based on a study of ca. 5,000 herbarium specimens (Hong 1966). Hong (1997) markedly expanded his list to include 259 taxa belonging to 76 genera in 37 families on the basis of personal collections and literature records for North Korean hepatics (Gao \& Chang 1981, 1983a, 1983b, 1983c, Kim 1991, Kim et al. 1995). Hong also provided identification keys to 263 known or expected taxa on the Korean Peninsula (Hong 2003).

Following in the footsteps of Hong, Choe conducted comprehensive bryofloristic research studies in South Korea. He published a manual on Korean Hepaticae, which included 201 taxa in 66 genera (Choe 1980). Later, in collaboration with the Japanese hepaticologist Yamada, 236 taxa of Hepaticae (Yamada \& Choe 1997) were assembled in a special checklist providing information on species' distributions within administrative provinces of both nations on the Korean Peninsula. They also recorded two species of Frullania new to the Korean Peninsula (Yamada \& Choe 2000).

More recently, Song \& Yamada (2006, 2009a, 2009b) examined the hepatic flora of Jeju Island (2006), Mt. Jiri (Jirisan) (2009a) and Mt. Gaya (Gayasan) (2009b). Lim (2006) reported nine taxa from Dongbaekdongsan on Jeju Island, and Lai et al. (2007) newly reported Lejeunea anisophylla Mont. for the Korean Peninsula. Park \& Choi (2007) published a list of bryophytes for the Korean Peninsula based on literature data. The list includes 281 taxa belonging in 81 genera. However, some species listed by Park \& Choi (2007) were recorded mistakenly or on the curious assumption that a taxon might occur in Korea.

Mt. Deogyu National Park has been a focus of floristic studies for the past several decades. The vascular plant flora has been exhaustively studied (Yim et al. 1994, Sun \& Park 1999, Yu 2007). Recently, Yoon (2009) investigated the moss flora of the park. He recorded 183 taxa (loc. cit.). Hong (1966) and Choe (1980) inventoried the hepatic flora on the mountain, but only 18 taxa were reported. Recently, Bakalin et al. (2008) reported Tetralophozia filiformis (Steph.) Urmi from the park; this was a first record for the Korean 
Peninsula. Since the hepatic flora of Mt. Deogyu has never been examined systematically, and only fragmentary floristic data are available for mountain ranges on the Korean Peninsula, we aimed to describe the hepatics of the area in as much detail as possible, providing information on altitudinal distribution and species ecology, as part of a compilation of data on the hepatic flora of Korea.

\section{RESEARCH AREA}

Mt. Deogyu National Park is located in the central part of the Korean Peninsula. It includes the northeastern region of Jellabuk-do Province and the northwestern region of Gyeongsangnam-do Province. The highest peaks are Hyangjeokbong (1,614 m a.s.l., central sector), Namdeogyusan (1,507 m a.s.l., southern sector), Jeoksangsan (1,034 m a.s.l., northwestern part), and Geochilbong (1,177 $\mathrm{m}$ a.s.l., northeastern sector). The park occupies $231.65 \mathrm{~km}^{2}$ and lies within the following coordinates: $127^{\circ} 40^{\prime} 30^{\prime \prime}-127^{\circ} 49^{\prime} 45^{\prime \prime} \mathrm{E}$ and $35^{\circ} 44^{\prime} 37^{\prime \prime}-36^{\circ} 59^{\prime} 40^{\prime \prime} \mathrm{N}$. The lowland area of the park is covered by broad-leaved deciduous forest that change to the forests of twisted conifers near the ridgelines. The mean annual temperature in the lowland area is $10.4^{\circ} \mathrm{C}$, and annual precipitation is $1,422 \mathrm{~mm}$. This mountainous area has a southern inland climate. The dominant rocks are granitic gneiss. Quaternary deposits are mostly formed from these rocks (Yim et al. 1994).

\section{MATERIALS AND METHODS}

Collections were concentrated in habitats where hepaticas are typically common and diverse, such as wet stones near stream beds, more or less dry rocks, bark of forest trees, exposed rocks and shaded cliffs near selected mountains tops (Fig. 1). We conducted 26 field surveys in a period between Oct. 2007 and Oct. 2009 at various sites in the park (Table 1).

All specimens were packed in newspaper or acid-free paper and annotated in the field with collection date, geographical coordinates, field herbarium number, collector, preliminary species name, substratum, and habitat. The collected materials were air-dried in the laboratory, and some species were cultivated in the greenhouse. The specimens we studied are kept in Chonbuk National University Herbarium (JNU, coll. S. S. Choi) and the herbarium of the Botanical Garden-Institute in Vladivostok (VBGI, coll. V. A. Bakalin). Specimens were identified by S. S. Choi and V. A. Bakalin in the course of a special collaborative project.

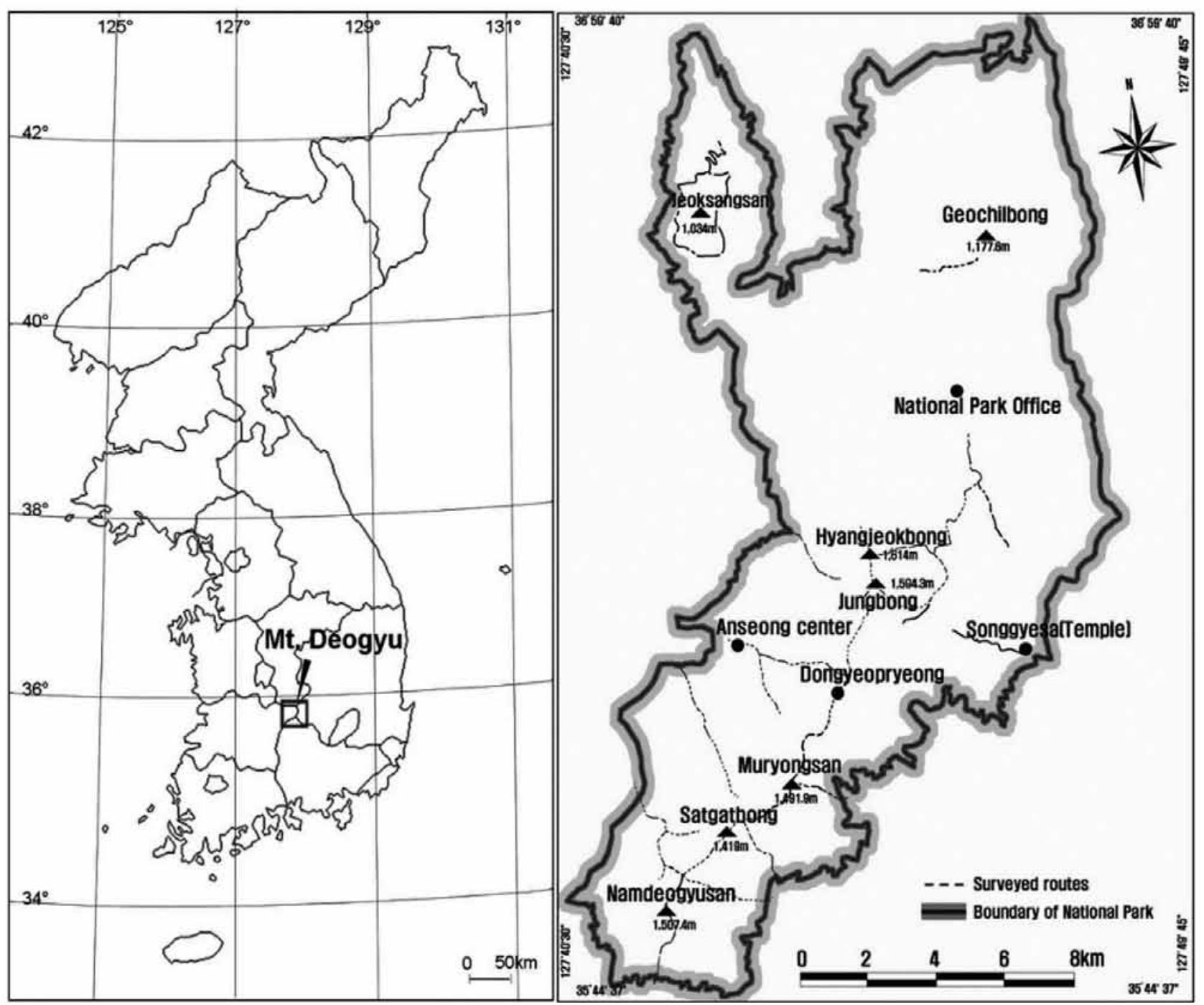

Figure 1 The position of Mt. Deogyu within Korean Peninsula and the surveyed routes of Mt. Deogyu in this study 
Table 1 Surveyed locals and dates of Mt. Deogyu

\begin{tabular}{|r|l|r|}
\hline No. & Locality & \multicolumn{1}{c|}{ Dates } \\
\hline 1 & Hyangjeokbong-Baegryeonsa area & 24.10 .2007 \\
\hline 2 & Songgyesa area & 30.10 .2007 \\
\hline 3 & Toyokdong stream & 28.11 .2007 \\
\hline 4 & Toyokdong stream & 01.12 .2007 \\
\hline 5 & Ansung-Chilyeon waterfall & 12.12 .2007 \\
\hline 6 & Uelsung stream & 19.03 .2008 \\
\hline 7 & Uelsung stream & 02.04 .2008 \\
\hline 8 & Guchendong stream & 27.04 .2008 \\
\hline 9 & Muryongsan area & 28.04 .2008 \\
\hline 10 & Chilyeon Waterfall & 22.05 .2008 \\
\hline 11 & Uelsung stream & 31.05 .2008 \\
\hline 12 & Meongchon stream & 07.06 .2008 \\
\hline 13 & Hyangjeokbong-Baekyeonsa area & $24-26.06 .2008$ \\
\hline 14 & Chilyeon waterfall & 27.06 .2008 \\
\hline 15 & Satgatgoljae area & 30.06 .2008 \\
\hline 16 & Deokgok stream & 01.07 .2008 \\
\hline 17 & Deokgok stream & 10.07 .2008 \\
\hline 18 & Satgatgoljae area & 18.09 .2008 \\
\hline 19 & Mt. Namdeogyusan & 30.10 .2008 \\
\hline 20 & Guchendong stream & 22.11 .2008 \\
\hline 21 & Guchendong-Baekyeonsa area & 15.12 .2008 \\
\hline 22 & Mt. Jeoksangsan & 14.03 .2009 \\
\hline 23 & Baekyeonsa-Osujagul area & 14.04 .2009 \\
\hline 24 & Mt. Namdeogyusan & 15.04 .2009 \\
\hline 25 & Toyokdong-Uelsungchi area & 14.05 .2009 \\
\hline 26 & Geochilbong area & 11.10 .2009 \\
\hline & & \\
\hline
\end{tabular}

\section{RESULTS AND DISCUSSION}

\section{Flora}

The checklist of hepatics on Mt. Deogyu includes 127 taxa from 28 families, 57 genera, 120 species, 4 subspecies, and 3 varieties. The list is based on critical study of 1538 herbarium specimens collected by S. S. Choi and V. A. Bakalin. The number of taxa corresponds to ca. $45 \%$ of the total hepatic taxonomic richness currently known for the Korean Peninsula. Among the taxa, seven species are new for the Republic of Korea. However, 3 species (Jubula japonica, Porella gracillima, Schistochilopsis incisa) among 18 taxa reported previously (Hong 1966, Choe 1980) were not found in the present study.

\section{Altitudinal distribution patterns}

Three main altitudinal categories were defined (Fig. 2):

1. Areas near the mountain top at elevations of 1400-1614 m a.s.1. Only 18 species were found above $1400 \mathrm{~m}$ a.s.l., including epilithic Arcto-Alpine taxa, such as Anastrophyllum assimile and Gymnomitrion commutatum.

2. Areas along ridges at elevations of 1000-1400 $\mathrm{m}$ a.s.1. Only eight species were found along ridges between $1000 \mathrm{~m}$ and $1400 \mathrm{~m}$ a.s.l., including a range of boreal epixylous taxa, such as Aneura pinguis and Cephalozia lacinulata.

3. Areas near streams at elevations below $1000 \mathrm{~m}$ a.s.l. Thirty-eight species were found below $1000 \mathrm{~m}$ a.s.l. The majority were restricted to wet habitats near streams,

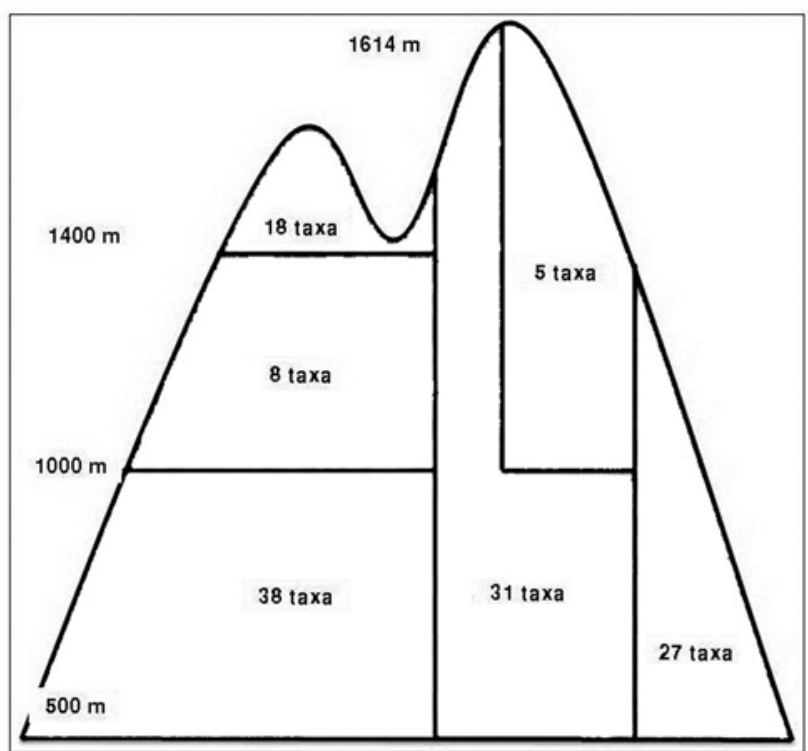

Figure 2 Altitudinal distributions of all taxa in Mt. Deogyu

valleys, and waterfalls; these included Chiloscyphus polyanthus and Geocalyx lancistipulus.

Three additional distribution categories were assigned to species occurring in at least two of three main altitudinal belts:

4. Areas above $1000 \mathrm{~m}$ a.s.1. Five species were found in the two categories above $1000 \mathrm{~m}$ a.s.l.; the most common were the boreal species Bazzania tricrenata and Cephalozia lunulifolia.

5. Areas between 500 and $1614 \mathrm{~m}$ a.s.1. Thirty-one species were found in each of the three main altitudinal categories.

6. Areas between elevations of $500 \mathrm{~m}$ and $1400 \mathrm{~m}$ a.s.l. Twenty-seven species occurred here.

Taxa newly recorded for the Republic of Korea, but previously found on the Korean Peninsula in the Korean People's Democratic Republic

1. Cephalozia lacinulata (J. B. Jack) Spruce

This species had been previously recorded from Mt. Myohyang and Mt. Geumgang (Kim 1991). We found it on decaying wood in a broad-leaved forest alongside the road from Jungbong to Baegryeonsa at an elevation of $1160 \mathrm{~m}$ a.s.l.

2. Cephalozia lunulifolia (Dumort.) Dumort.

This species had been previously recorded from Chailbong (Bujeon), Seonggan, Nanglim Mountans, and Mt. Heulryeong (Kim 1991). We found it on wet cliffs in a broad-leaved forest with a coniferous admixture alongside the road from Jungbong to Baegryeonsa at an elevation of $1160-1245 \mathrm{~m}$ a.s.l.

\section{Odontoschisma denudatum (Nees) Dumort.}

This species had been previously recorded for Mt. Myohyang and Mt. Geumgang (Kim, 1991). On Mt. Deogyu, we found it on decaying wood in broad-leaved forests near the Chilyeon waterfall and in the Hyangjeokbong area at elevation of $680-1500 \mathrm{~m}$ a.s.l. 
4. Plicanthus hirtellus (F. Weber) R. M. Schust.

This species had been previously recorded from Mt. Maengbu (Kim, 1991). We found it on cliffs along Meongchon stream in a broad-leaved forest at an elevation of $689 \mathrm{~m}$ a.s.l.

\section{Geocalyx lancistipulus (Steph.) S. Hatt.}

This species had been previously recorded from Mt. Oga (Kim 1991). We found it on shaded rocks along Toyokdong streams in broad-leaved forests at an elevation of $820 \mathrm{~m}$ a.s.l.

6. Hattorianthus erimonus (Steph.) R. M. Schust. \& H. Inoue

This species had been previously recorded from Mt. Chilbo, Yangdok and Sambang (Kim 1991). We found it on the wet soil near Uelsung and Guchendong streams in broad-leaved forests.

7. Riccardia multifida var. decrescens (Steph.) Furuki

This variety had been previously recorded from Mt. Baekdu, Mt. Chilbo, Yangdok, Mt. Myohang, and in Seonggan and Chanseong provinces (Kim, 1991). We found it on wet cliffs alongside the road from Baegryeonsa to Osujagul Cave at $1446 \mathrm{~m}$ a.s.l.

\section{LIST OF SPECIES}

Taxa are arranged alphabetically. Nomenclature for taxa in the list follows Konstantinova et al. (2009); when taxa were absent from Konstantinova et al. (2009), we followed Yamada \& Iwatsuki (2006). Each species is annotated as follows: 1) sexual and asexual reproduction organs present: spor. - sporogonia; arch. - archegonia; ant. - antheridia; per. - perianthia; gemm. - gemmae; 2) habitats; 3) altitudinal range in the area studied; 4) accompanying taxa; 5) selected voucher specimen number (S. S. Choi's collections are prefixed by SC, V. A. Bakalin's collections are prefixed by VB); 6) data on oil bodies in mid-leaf cells are included for some species; variation in this parameter is poorly understood for many East Asian species.

Anastrophyllum assimile (Mitt.) Steph. - shaded cliffs and rocks in Quercus forest; $1446 \mathrm{~m}$ a.s.l.; 15.04.2009, SC 13492 (JNU), 15.04.2009, SC 13496 (JNU).

Aneura pinguis (L.) Dumort. - wet cliffs along stream in broad-leaved forest mixed with conifers; $1200 \mathrm{~m}$ a.s.l.; 02 Apr. 2008, SC 10303 (JNU), 22 May 2008, SC 10572 (JNU), 26 Jun. 2008, VB Kor-11-10-08 (VBGI).

Apometzgeria pubescens (Schrank) Kuwah. - wet cliffs along stream in broad-leaved forest mixed with conifers; with Porella fauriei, Porella grandiloba; 600-1160 m a.s.l.; 28 Nov. 2007, SC 10078 (JNU), 28.11.2007, SC 10780 (JNU), 26 Jun. 2008, VB Kor-11-27-08 (VBGI).

Asterella cruciata (Steph.) Horik. - spor.; rocks along stream in broad-leaved forest; $810 \mathrm{~m}$ a.s.l.; 30.06.2008, SC 10879 (JNU), 30 Jun. 2008, SC 10880 (JNU), 30 Jun. 2008, VB Kor-16-3-08 (VBGI).

Bazzania bidentula (Steph.) Steph. ex Yasuda - shaded rocks in Alnus thickets; 880-1580 m a.s.l.; 25 Jun. 2008, SC 10707 (JNU), 25 Jun. 2008, SC 10721 (JNU), 25 Jun. 2008, VB Kor-9-20-08 (VBGI).

Bazzania denudata (Torr. ex Lindenb.) Trevis. - decaying wood, shaded rocks and cliffs in broad-leaved forests, fine-grained soil along roadside; in pure mats or with Blepharostoma minus, Cephalozia lunulifolia, Diplophyllum taxifolium, Lophocolea minor, Marsupella tubulosa var. patens, Metrgeria furcata var. ulvula; 549-1400 $\mathrm{m}$ a.s.l.; 01 Dec. 2007, SC 10145 (JNU), 27 Jun. 2008, SC 10836 (JNU), 24 Jun. 2008, VB Kor-7-2-08 (VBGI), 27 Jun. 2008, VB Kor-14-19-08 (VBGI).

Bazzania japonica (Sande Lac.) Lindb. - decaying wood in broad-leaved forest; $1400 \mathrm{~m}$ a.s.l.; 24 Jun. 2008, SC 10632 (JNU), 30 Oct. 2008, SC 11124 (JNU), 24 Jun. 2008, VB Kor-7-1-08 (VBGI).

Bazzania tricrenata (Wahlenb.) Trevis. - shaded rocks and wet cliffs along streams in broad-leaved forests; in pure mats or with Plagiochila sciophila, Scapania ciliata, S. integerrima; 1160-1584 m a.s.l.; 24 Jun. 2008, SC 10630 (JNU), 25 Jun. 2008, SC 10695 (JNU), 24 Jun. 2008, VB Kor-9-308 (VBGI), 26 Jun. 2008, VB Kor-11-28a-08 (VAL).

Blepharostoma minus Horik. - cliffs along streams in broadleaved forest; in pure mats or with Bazzania denudata, Herbertus sp. Tetralophozia filiformis; 549-1444 m a.s.l.; 12 Dec. 2007, SC 10117 (JNU), 19 Mar. 2008, SC 10235 (JNU), 27 Jun. 2008, VB Kor-14-19-08 (VBGI), 1 Jul. 2008, VB Kor-17-35-08 (VBGI).

Blepharostoma trichophyllum (L.) Dumort. - wet cliffs along stream in broad-leaved forest mixed with conifers; in pure mats or with Plagiochila trabeculata, Radula japonica; 600-1444 m a.s.l.; 22 May 2008, SC 10565 (JNU), 24 Jun. 2008, SC 10669 (JNU), 26 Jun. 2008, VB Kor-11-5-08 (VBGI).

Calycularia crispula Mitt. - arch.; wet shade rocks and cliffs along streams in broad-leaved forsts; 809-1446 m a.s.l.; 24 Oct. 2007, SC 10007 (JNU), 25 Jun. 2008, SC 10730 (JNU), 25 Jun. 2008, VB Kor-10-20-08 (VBGI), 30 Jun. 2008, VB Kor-16-18-08 (VBGI).

Calypogeia arguta Nees et Mont. - gemm.; wet cliffs along streams and fine-grained soil along roadside in broadleaved forests; 518-1234 m a.s.l.; 28 Nov. 2007, SC 10086 (JNU), 01 Dec. 2007, SC 10157 (JNU), 26 Jun. 2008, VB Kor-11-34-08 (VBGI), 27 Jun. 2008, VB Kor13-14-08 (VBGI).

Calypogeia azurea Stotler et Crotz. - wet cliffs along stream in broad-leaved forest; with Jungermannia subulata; $1200 \mathrm{~m}$ a.s.l.; 26 Jun. 2008, VB Kor-11-35a-08 (VBGI).

Calypogeia tosana (Steph.) Steph. - cliffs and rocks along streams, fine-grained soil along roadside in broad-leaved forests; in pure mats or with Cephalozia lunulifolia; 600 1458 m a.s.l.; 27 Apr. 2008, SC 10393 (JNU), 22 May 2008, SC 10524 (JNU), 24 Jun. 2008, VB Kor-8-2-08 (VBGI), 30 Jun. 2008, VB Kor-16-6-08 (VBGI).

Cephalozia cf. catenulata (Huebener) Lindb. ssp. nipponica (S. Hatt.) H. Inoue - rocks along stream in broad-leaved forest; $1200 \mathrm{~m}$ a.s.l.; 30 Jun. 2008, VB Kor-16-7-08 (VBGI).

Cephalozia lacinulata (J. B. Jack ex Gottsche \& Rabenh.) Spruce - decaying wood in broad-leaved forest; $1160 \mathrm{~m}$ a.s.l.; 26 Jun. 2008, SC 10777 (JNU), 27 Jun. 2008, SC 10846 (JNU).

Cephalozia lunulifolia (Dumort.) Dumort. - wet cliffs along stream in broad-leaved forest mixed with conifers, finegrained soil along roadside in broad-leaved forest; in pure mats or with Bazzania denudata, Calypogeia tosana, Diplophyllum taxifolium; 1160-1458 m a.s.l.; 27 Apr. 2008, SC 10396 (JNU), 24 Jun. 2008, SC 10668 (JNU), 24 Jun. 2008, VB Kor-8-4-08 (VBGI), 26 Jun. 2008, VB Kor-1115-08 (VBGI).

Cephalozia otaruensis Steph. - per., spor.; wet cliffs along stream in broad-leaved forest, decaying wood in broadleaved forest mixed with conifers; in pure mats or with Jungermannia subulata; 549-1444 m a.s.l.; 1 Dec. 2007, SC 
10155 (JNU), 19 Mar. 2008, SC 10246 (JNU), 26 Jun. 2008, VB Kor-11-32-08 (VBGI), 27 Jun. 2008, VB Kor14-2-08 (VBGI).

Cephaloziella divaricata (Sm.) Warnst. - ant.; rocks crevices shaded by Alnus; 1576 m; 25 Jun. 2008, SC 10709 (JNU), 24 Jun. 2008, VB Kor-9-19-08 (VBGI).

Cephaloziella hampeana (Nees) Schiffner ex Loeske - shaded cliffs and rocks in Quercus forest; $1421 \mathrm{~m}$ a.s.l.; 27 Jun. 2008, SC 10801 (JNU), 30 Jun. 2008, SC 10867 (JNU).

Cephaloziella microphylla (Steph.) Douin - fine-grained soil along roadside in broad-leaved forest; 580-1446 $\mathrm{m}$ a.s.l.; 02 Apr. 2008, SC 10585 (JNU), 15 Apr. 2009, SC 13489 (JNU).

Cephaloziella spinicaulis Douin - shade stones, rocks, cliffs along stream in broad-leaved and mixed forests; in pure mats or with Macvicaria ulophylla; 625-1437 m a.s.l.; 02 Apr. 2008, SC 10341 (JNU), 24 Jun. 2008, SC 10641 (JNU), 24 Jun. 2008, VB Kor-7-7-08 (VBGI), 1 Jul. 2008, VB Kor-17-9-08 (VBGI).

Cephaloziella spinigera (Lindb.) Jørg. - shaded cliffs and rocks in Ouercus spp. forest; $1421 \mathrm{~m}$ a.s.l.; 30 Oct. 2008, SC 11107 (JNU).

Cheilolejeunea obtusifolia (Steph.) S. Hatt. - shaded cliffs and rocks (mainly along streams) in broad-leaved forests; 549-1576 m a.s.l.; 01 Dec. 2007, SC 10104 (JNU), 27 Apr. 2008, SC 10379 (JNU), 24 Jun. 2008, VB Kor-811-08 (VBGI), 1 Jul. 2008, VB Kor-17-14-08 (VBGI); oil-bodies 2-3 per cells, fusiform, 10-12 $\times 4 \mu \mathrm{m}$.

Chiloscyphus polyanthus (L.) Corda. - wet cliffs along streams in broad-leaved and mixed forests; in pure mats or with Lejeunea japonica, Xenochila integrifolia; 690-840 m a.s.l.; 30 Oct. 2007, SC 10017 (JNU), 1 Dec. 2007, SC 10103 (JNU), 26 Jun. 2008, VB Kor-11-11-08, 1 Jul. 2008, VB Kor-17-10-08 (VBGI).

Cololejeunea longifolia (Mitt.) Benedix - cliffs along stream in broad-leaved forest; 549-880 m a.s.l.; 1 Dec. 2007, SC 10121 (JNU), 19 Mar. 2008, SC 10223 (JNU), 1 Jul. 2008, VB Kor-17-2-08 (VBGI).

Cololejeunea macounii (Spruce ex Underw.) A. Evans - per.; shaded stones and cliffs along streams in broad-leaved forests; in pure mats or with Frullania tamarisci ssp. obscura; 625-880 m a.s.l.; 1 Jul. 2008, SC 10921 (JNU), 10 Jul. 2008, SC 10992 (JNU), 24 Jun. 2008, VB Kor-7-1108 (VBGI), 1 Jul. 2008, VB Kor-17-6-08 (VBGI).

Cololejeunea ornata A. Evans - bark of broad-leaved trees in broad-leaved forest; $880 \mathrm{~m}$ a.s.l.; 15 Dec. 2008, SC 11205 (JNU).

Conocephalum conicum (L.) Underw. - wet cliffs and humic soil along streams in broad-leaved forests, very wet and shady rocky wall in small grotto; in pure mats and with Jungermannia subulata, Pellia endiviifolia; 518-1245 m a.s.l.; 24 Oct. 2007, SC 10001 (JNU), 14 Mar. 2009, SC 13405 (JNU), 26 Jun. 2008, VB Kor-11-17-08 (VBGI), 30 Jun. 2008, VB Kor-15-1-08 (VBGI).

Conocephalum japonicum (Thunb.) Grolle - very wet and shaded rocky wall in small grotto, cliffs along stream in broad-leaved forest; in pure mats or with Radula japonica; 723-1155 m a.s.l.; 24 Oct. 2007, SC 10013 (JNU), 27 Jun. 2008, SC 10793 (JNU), 27 Jun. 2008, VB Kor-12-1-08 (VBGI), 27 Jun. 2008, VB Kor-14-41-08 (VBGI).

Crossogyna autumnalis (DC.) Schljakov - per.; shaded rocks and wet cliffs along streams in broad-leaved and mixed forests; in pure mats or with Lejeunea compacta, Pedinophyllum truncatum, Scapania undulata, Trichocoleopsis sacculata; 690-1580 m a.s.l.; 30 Oct. 2007, SC 10016 (JNU), 15 Apr. 2009, SC 13483 (JNU), 24 Jun. 2008, VB Kor-9-1-08 (VBGI), 01 Jul. 2008, VB Kor-17-31-08
(VBGI).

Cylindrocolea recurvifolia (Steph.) H. Inoue - shaded stones, rocks, cliffs along stream in broad-leaved and mixed forests; 667-1234 m a.s.l.; 27 Jun. 2008, SC 10807 (JNU), 30 Jun. 2008, SC 10868 (JNU).

Dicranolejeunea yoshinagana (S. Hatt.) Mizut. - very wet rocks along stream in broad-leaved forest; 576-629 $\mathrm{m}$ a.s.l.; 19 Mar. 2008, SC 10236 (JNU), 7 Jun. 2008, SC 10584 (JNU).

Diplophyllum albicans (L.) Dumort. - cliffs and rocks along streams in broad-leaved and mixed forests; $580-1446 \mathrm{~m}$ a.s.l.; 07 Jun. 2008, SC 10619 (JNU), 26 Jun. 2008, SC 10771 (JNU), 26 Jun. 2008, VB Kor-11-39-08 (VBGI), 30 Jun. 2008, VB Kor-16-17-08 (VBGI).

Diplophyllum serrulatum (Müll. Frib.) Steph. - ant., per., gemm.; cliffs along streams in broad-leaved forests; 580 760 m a.s.l.; 7 Jun. 2008, SC 10595 (JNU), 27 Jun. 2008, SC 10806 (JNU), 27 Jun. 2008, VB Kor-13-2-08 (VBGI), 1 Jul. 2008, VB Kor-17-4-08 (VBGI).

Diplophyllum taxifolium (Wahlenb.) Dumort. - cliffs and rocks along streams in broad-leaved and mixed forests; 680-1160 m a.s.l.; 26 Jun. 2008, SC 10783 (JNU), 27 Jun. 2008, SC 10813 (JNU).

Frullania appendiculata Steph. - ant.; cliffs and rocks along streams, stones and bark of Quercus mongolica in broadleaved forests; in pure mats or with Cololejeunea macounii, Frullania davurica, Plicanthus birmensis; 690-1580 m a.s.l.; 28 Nov. 2007, SC 10091 (JNU), 15 Dec. 2008, SC 11178 (JNU), 24 Jun. 2008, VB Kor-7-10-08 (VBGI), 1 Jul. 2008, VB Kor-17-20-08 (VBGI).

Frullania davurica Hampe. - shaded cliffs and rocks in broadleaved and mixed forests; in pure mats or with Frullania tamarisci ssp. obscura, Lejeunea japonica; 518-1437 m a.s.l.; 28 Nov. 2007, SC 10052 (JNU), 1 Dec. 2007, SC 10109 (JNU), 24 Jun. 2008, VB Kor-9-3a-08, 1 Jul. 2008, VB Kor-17-17-08 (VBGI).

Frullania diversitexta Steph. - bark of broad-leaved trees (Quercus mongolica) in broad-leaved forest; 723-1584 m a.s.l.; 25 Jun. 2008, SC 10680 (JNU), 10 Jul. 2008, SC 11016 (JNU).

Frullania inflata Gottsche - shaded cliffs along stream in broad-leaved forest; 625 m a.s.l.; 1 Jul. 2008, SC 10937 (JNU).

Frullania kagoshimensis Steph. - shaded cliffs along stream in broad-leaved forest; 625 m a.s.l.; 1 Jul. 2008, SC 10903 (JNU).

Frullania muscicola Steph. - arch.; shaded rocks, cliffs along stream, bark of trees in broad-leaved forests and Alnus thickets; 625-1580 m a.s.l.; 24 Jun. 2008, SC 10654 (JNU), 14 Mar. 2009, SC 13411 (JNU), 24 Jun. 2008, VB Kor-7-18-08 (VBGI), 1 Jul. 2008, VB Kor-17-34-08 (VBGI).

Frullania polyptera Tayl. - per.; bark of broad-leaved trees in broad-leaved forest; $720 \mathrm{~m}$ a.s.l.; 27 Jun. 2008, SC 10837 (JNU), 27 Jun. 2008, VB Kor-14-3-08 (VBGI).

Frullania taradakensis Steph. - per., spor.; bark of broadleaved trees and Abies koreana, cliffs along streams in broad-leaved and mixed forests; $690-1580 \mathrm{~m}$ a.s.l.; 28 Nov. 2007, SC 10033 (JNU), 22 Nov. 2008, SC 11151 (JNU), 24 Jun. 2008, VB Kor-7-17-08 (VBGI), 1 Jul. 2008, VB Kor-17-22-08 (VBGI).

Frullania usamiensis Steph. - bark of broad-leaved trees in broad-leaved forest; with Frullania taradakensis; 234-1584 m a.s.l.; 25 Jun. 2008, SC 10679 (JNU), 18 Sep. 2008, SC 11043 (JNU).

Geocalyx cf. lancistipulus (Steph.) S. Hatt. - shaded rocks 
along streams in broad-leaved forests; $820 \mathrm{~m}$ a.s.l.; 1 Dec. 2007, SC 10156 (JNU), 1 Dec. 2007, SC 10159 (JNU).

Gymnomitrion alpinum (Gottsche ex Husn.) Schiffn. - shaded cliffs and rocks in Quercus forest; $1421 \mathrm{~m}$ a.s.l.; 30 Oct. 2008, SC 11097 (JNU).

Gymnomitrion commutatum (Limpr.)Schiffn. - shaded cliffs and rocks in Quercus forest; $1421 \mathrm{~m}$ a.s.l.; 30 Oct. 2008, SC 11105 (JNU), 30 Oct. 2008, SC 11106 (JNU).

Hattorianthus erimonus (Steph.) R. M. Schust. \& H. Inoue humic soil along stream in broad-leaved forest; with Conocephalum conicum; $650 \mathrm{~m}$ a.s.l.; 19 Mar. 2008, SC 10272 (JNU), 30 Jun. 2008, VB Kor-15-1-08 (VBGI).

Herbertus aduncus (Dicks.) Gray - shaded cliffs along stream in broad-leaved forest with admixture of conifers; 7231234 m a.s.l.; 10 Jul. 2008, SC 10982 (JNU), 18 Aug. 2008, SC 11056 (JNU).

Herbertus buchii Juslén - rock outcrops in full sun, broadleaved forest mixed with conifers and shrubs; 14371584 m a.s.l.; 05 Jun. 2008, SC 10682 (JNU), 30 Oct. 2008, SC 11096 (JNU). Although we accept here this taxon at species level, its rank requires further study. Most probably it represents only depauperate form of H. dicranus. We studied the isotype of the species (VBGI) and found material very diverse with the most developed plants indistinguishable from typical $H$. dicranus.

Herbertus dicranus (Taylor) Trevis. - shaded cliffs in broadleaved forest mixed with conifers and shrubs, rock outcrops in full sun; in pure mats or with Plicanthus birmensis; 690-1580 m a.s.l.; 25 Jun. 2008, SC 10691 (JNU), 10 Jul. 2008, SC 11031 (JNU), 24 Jun. 2008, VB Kor-9-12-08 (VBGI), 1 Jul. 2008, VB Kor-17-43-08 (VBGI).

Heteroscyphus planus (Mitt.) Schiffn. - cliffs along stream in broad-leaved forest; 690 m a.s.l.; 1 Jul. 2008, VB Kor-173-08 (VBGI); oil-bodies 9-12 per cells, spherical, filling lumen.

Jubula hutchinsiae (Hook.) Dumort. ssp. javanica (Steph.) Verd - very wet and shaded rocky wall in small grotto; $640 \mathrm{~m}$ a.s.l.; 19 Mar. 2008, SC 10277 (JNU), 27 Jun. 2008, SC 10797 (JNU), 27 Jun. 2008, VB Kor-12-6-08 (VBGI).

Jubula japonica Steph. - only literature record (Hong 1966).

Jungermannia atrovirens Dumort. - wet cliffs and rocks along stream in broad-leaved forest; 600-1245 $\mathrm{m}$ a.s.l.; 19 Mar. 2008, SC 10283 (JNU), 14 Apr. 2009, SC 13430 (JNU).

Jungermannia exsertifolia Steph. - ant.; cliffs along stream in broad-leaved forest; 720 m a.s.l.; 27 Jun. 2008, VB Kor14-14-08 (VBGI).

Kurzia makinoana (Steph.)Grolle. - per.; cliffs along stream in broad-leaved forest; 580-1446 m a.s.l.; 7 Jun. 2008, SC 10620 (JNU), 15 Apr. 2009, SC 13482 (JNU), 27 Jun. 2008, VB Kor-14-20-08 (VBGI).

Lejeunea compacta (Steph.)Steph. - shaded cliffs in broadleaved forest mixed with conifers and shrubs; in pure mats or with Jamesoniella autumnalis; $880-1330 \mathrm{~m}$ a.s.l.; 30 Oct. 2008, SC 11126 (JNU), 15 Dec. 2008, SC 11182 (JNU), 25 Jun. 2008, VB Kor-10-10-08 (VBGI).

Lejeunea japonica Mitt. - per.; cliffs along streams, very wet and shaded rocky wall in small grotto, fine-grained soil along streams in broad-leaved and mixed forests; in pure mats or with Chiloscyphus polyanthos, Frullania davurica, Metzgeria conjugata, Xenochila integrifolia; 640-1446 m a.s.l.; 28 Nov. 2007, SC 10032 (JNU), 15 Apr. 2009, SC 13484 (JNU), 26 Jun. 2008, VB Kor-11-8-08 (VBGI), 1 Jul. 2008, VB Kor-17-10-08 (VBGI).

Lejeunea parva (S. Hatt.) Mizut. - very wet and shaded rocky wall in small grotto, cliffs along stream in broad-leaved forest; 662-1444 m a.s.l.; 19 Mar. 2008, SC 10293 (JNU), 30 Oct. 2008, SC 11123 (JNU), 27 Jun. 2008, VB Kor-123-08 (VBGI), 27 Jun. 2008, VB Kor-14-18-08 (VBGI); oil-bodies 2-5(6) per cell.

Lejeunea ulicina (Taylor) Gottsche - shaded cliffs and rocks in Quercus forest; with Radula cavifolia, Cephaloziella spinigera; $1421 \mathrm{~m}$ a.s.l.; 30 Oct. 2008, SC 11107 (JNU).

Lepidozia reptans (L.) Dumort. - decaying wood in mixed forest; $1576 \mathrm{~m}$ a.s.l.; 25 Jun. 2008, SC 10699 (JNU), 25 Jun. 2008, SC 10700 (JNU), 24 Jun. 2008, VB Kor-9-2708 (VBGI).

Liochlaena subulata (A. Evans) Schljakov - per., gemm.; wet cliffs and humic soil in broad-leaved and mixed forests, very wet and shady rocky wall in small grotto; in pure mats or with Calypogeia azurea, Cephalozia otaruensis, Conocephalum conicum; 580-1160 m a.s.l.; 27 Apr. 2008, SC 10363 (JNU), 15 Dec. 2008, SC 11214 (JNU), 26 Jun. 2008, VB Kor-11-35-08 (VBGI), 1 Jul. 2008, VB Kor17-18-08 (VBGI).

Lophocolea bidentata (Nees) Fulford - wet cliffs and rocks along stream in broad-leaved forest; $723 \mathrm{~m}$ a.s.l.; $10 \mathrm{Jul}$. 2008, SC 10994 (JNU), 10 Jul. 2008, SC 11003 (JNU).

Lophocolea heterophylla (Schrad.) Dumort. - wet cliffs along stream in broad-leaved forest mixed with conifers; 576-1245 m a.s.l.; 19 Mar. 2008, SC 10242 (JNU), 10 Jul. 2008, SC 10975 (JNU).

Lophocolea horikowana S. Hatt. mod. minuta - cliffs along stream in broad-leaved forest; 720 m a.s.l.; 27 Jun. 2008, VB Kor-14-10-08 (VBGI).

Lophocolea itoana Inoue - decaying wood in broad-leaved forest; $680 \mathrm{~m}$ a.s.l.; 1 Dec. 2007, SC 10112 (JNU), 15 Dec. 2008, SC 11187 (JNU).

Lophocolea minor Nees. - gemm.; shaded stone in broadleaved forest; in pure mats or with Bazzania denudata, Marsupella emarginata var. tubulosa; 518-1505 m a.s.l.; 28 Nov. 2007, SC 10041 (JNU), 22 Nov. 2008, SC 11146 (JNU), 24 Jun. 2008, VB Kor-7-3-08 (VBGI).

Makinoa crispata (Steph.) Miyake - shaded rocks along stream in broad-leaved forest; $680 \mathrm{~m}$ a.s.l.; 02 Apr. 2008, SC 10306 (JNU), 2 Apr. 2008, SC 10307 (JNU).

Marchantia polymorpha ssp. montivagans Bischl. \& BoiselierDubayle - fine-grained soil along roadside in broadleaved forest; $950 \mathrm{~m}$ a.s.l.; 24 Jun. 2008, SC 10656 (JNU), 24 Jun. 2008, SC 10671 (JNU), 24 Jun. 2008, VB Kor-81-08 (VBGI).

Marchantia polymorpha L. ssp. polymorpha - wet fine-grained soil along roadside in broad-leaved forest; $580 \mathrm{~m}$ a.s.l.; 28 Nov. 2007, SC 10030 (JNU), 22 May 2008, SC 10574 (JNU).

Marsupella emarginata (Ehrh.) Dumort. subsp. tubulosa (Steph.) N. Kitag. - ant., per.; Shaded stones, rocks, cliffs in broad-leaved and mixed forests; in pure mats or with Bazzania denudata, Lophocolea minor, Scapania integerrima; 640-1580 m a.s.l.; 19 Mar. 2008, SC 10294 (JNU), 15 Dec. 2008, SC 11215 (JNU), 24 Jun. 2008, VB Kor-7-308 (VBGI), 27 Jun. 2008, VB Kor-13-4-08 (VBGI).

Marsupella pseudofunckii S. Hatt. - per.; cliffs along streams, fine-grained soil along roadside in broad-leaved forests; in pure mats or with Scapania undulata; 625-1584 $\mathrm{m}$ a.s.l.; 22 May 2008, SC 10509 (JNU), 14 Apr. 2009, SC 13459 (JNU), 24 Jun. 2008, VB Kor-8-3-08 (VBGI), 1 Jul. 2008, VB Kor-17-15-08 (VBGI).

Marsupella yakushimensis (Horik.) S. Hatt. - wet cliffs along stream in broad-leaved forest mixed with conifers; 880$1501 \mathrm{~m}$ a.s.l.; 24 Jun. 2008, SC 10653 (JNU), 15 Dec. 2008, SC 11209 (JNU), 26 Jun. 2008, VB Kor-11-41-08 (VBGI). 
Metacalypogeia cordifolia (Steph.) H. Inoue - wet cliffs along stream in broad-leaved forest with admixture of conifers; 1200 m a.s.l.; 30 Oct. 2007, SC 10018 (JNU), 27 Jun. 2008, SC 10803 (JNU), 26 Jun. 2008, VB Kor11-40-08 (VBGI).

Metzgeria lindbergii Schiffn. - shaded stone, wet cliffs along stream in broad-leaved forests, very wet and shaded rocky walls in small grotto; in pure mats or with Lejeunea japonica; 640-1400 m a.s.l.; 28 Nov. 2007, SC 10079 (JNU), 14 Mar. 2009, SC 13410 (JNU), 24 Jun. 2008, VB Kor-7-6-08 (VBGI), 27 Jun. 2008, VB Kor-12-2-08 (VBGI).

Metzgeria furcata (L.) Corda - shaded stone in broad-leaved forest on a slope; $1400 \mathrm{~m}$ a.s.l.; 24 Jun. 2008, SC 10635 (JNU), 24 Jun. 2008, SC 10651 (JNU), 24 Jun. 2008, VB Kor-7-14-08 (VBGI).

Metageria temperata Kuwah. - wet cliffs along stream in broad-leaved forest mixed with conifers; $1200 \mathrm{~m}$ a.s.l.; 15 Dec. 2008, SC 11190 (JNU), 26 Jun. 2008, VB Kor11-28-08 (VBGI).

Nardia assamica (Mitt.) Amak. - fine-grained soil along roadside in broad-leaved forest; 1234-1458 m a.s.l.; 24 Jun. 2008, SC 10673 (JNU), 18 Sep. 2008, SC 11051 (JNU), 24 Jun. 2008, VB Kor-8-5-08 (VBGI); 1 large oil-body per $15 \%$ midleaf cells, $7.5-10 \times 5-7.5 \mu \mathrm{m}$.

Nipponolejeunea pilifera (Steph.) S. Hatt. - shaded rocks and cliffs in broad-leaved forest mixed with conifers and shrubs and in Alnus thicket; 1437-1584 m a.s.l.; 24 Jun. 2008, SC 10636 (JNU), 30 Oct. 2008, SC 11113 (JNU), 24 Jun. 2008, VB Kor-9-5-08 (VBGI), 25 Jun. 2008, VB Kor-10-6-08 (VBGI).

Odontoschisma denudatum (Nees) Dumort. - decaying wood in broad-leaved forest; 600-1498 m a.s.l.; 22 May 2008, SC 10563 (JNU), 27 Jun. 2008, SC 10847 (JNU), 27 Jun. 2008, VB Kor-14-1-08 (VBGI).

Pedinophyllum interruptum (Nees) Kaal. - shaded rocks in broad-leaved forest; 950 m a.s.l.; 27 Jun. 2008, SC 10858 (JNU), 24 Jun. 2008, VB Kor-8-10-08 (VBGI); oil-bodies 3-7 per midleaf cell.

Pedinophyllum truncatum (Steph.) H. Inoue. - per.; cliffs along stream in broad-leaved and mixed forests; in pure mats or with Jamesoniella autumnalis, Trichocoleopsis sacculata; 690-1200 m a.s.l.; 2 Apr. 2008, SC 10305 (JNU), 10 Jul. 2008, SC 11000 (JNU), 26 Jun. 2008, VB Kor-11-2508 (VBGI), 1 Jul. 2008, VB Kor-17-12-08 (VBGI); oilbodies 8-15 per midleaf cell.

Pellia endiviifolia (Dicks.) Dumort. - ant.; crevices of shaded rocks in Alnus thicket, very wet and shaded rocky wall in small grotto; in pure mats or with Conocephalum conicum; 640-1580 m a.s.l.; 28 Nov. 2007, SC 10029 (JNU), 14 May 2009, SC 13586 (JNU), 24 Jun. 2008, VB Kor-9-2108, 27 Jun. 2008, VB Kor-12-8-08 (VBGI).

Pellia neesiana (Gottsche) Limpr. - cliffs in the broad-leaved forest; $998 \mathrm{~m}$ a.s.l.; 19 Mar. 2008, SC 10228, 14 Apr. 2009, SC 13461 (JNU), 27 Jun. 2008, VB Kor-13-1-08 (VBGI).

Plagiochila hakkodensis Steph. - wet cliffs along stream in broad-leaved forest mixed with conifers; with Trichocoleopsis sacculata; $1200 \mathrm{~m}$ a.s.l.; 26 Jun. 2008, VB Kor-11-13-08 (VBGI).

Plagiochila ovalifolia Mitt. - shaded cliffs and rocks, mainly along stream in broad-leaved and mixed forests; in pure mats or with Kurzia makinoana, Porella fauriei, Porella vernicosa, Radula japonica; 720-1580 m a.s.l.; 19 Mar. 2008, SC 10220 (JNU), 19 Mar. 2008, SC 10234 (JNU), 24 Jun. 2008, VB Kor-9-7-08 (VBGI), 30 Jun. 2008, VB Kor-1619a-08 (VBGI).
Plagiochila porelloides (Torrey in Nees.) Lindenb. - wet cliffs and rocks along streams in broad-leaved and mixed forests; 1576 m a.s.l.; 25 Jun. 2008, SC 10703 (JNU).

Plagiochila sciophila Nees ex Lindenb. - wet cliffs and rocks along streams in broad-leaved and mixed forests; in pure mats or with Bazzania tricrenata; $810-1200 \mathrm{~m}$ a.s.l.; 28 Nov. 2007, SC 10069 (JNU), 14 Apr. 2009, SC 13455 (JNU), 26 Jun. 2008, VB Kor-11-20-08 (VBGI), 30 Jun. 2008, VB Kor-16-3a-08 (VAL); oil-bodies 4-7 per midleaf cell, elliptic.

Plagiochila semidecurrens Lehm. et Lindenb. - shaded rocks in Alnus thicket; 1580 m a.s.l.; 24 Jun. 2008, VB Kor-9-9-08 (VBGI).

Plagiochila trabeculata Steph. - shaded stones, rocks, cliffs, mainly near springs in broad-leaved and mixed forests; in pure mats or with Blepharostoma trichophyllum, Radula japonica; 950-1400 m a.s.l.; 24 Jun. 2008, SC 10649 (JNU), 25 Jun. 2008, SC 10678 (JNU), 24 Jun. 2008, VB Kor-712-08 (VBGI), 26 Jun. 2008, VB Kor-11-4-08 (VBGI).

Plectocolea erecta Amakawa - wet cliffs in Quercus forest; 1444 m a.s.l.; 15 Apr. 2009, SC 13499 (JNU).

Plectocolea byalina (Lyell) Mitt. - wet fine-grained soil along roadside; $1481 \mathrm{~m}$ a.s.l.; 24 Jun. 2008, SC 10633 (JNU), 24 Jun. 2008, SC 10639 (JNU).

Plectocolea infusca Mitt. var. infusca - ant., arch.; cliffs and rocks mainly near stream in broad-leaved forests; 640-809 m a.s.l.; 27 Apr. 2008, SC 10368 (JNU), 10 Jul. 2008, SC 10996 (JNU), 27 Jun. 2008, VB Kor-13-7-08 (VBGI), 30 Jun. 2008, VB Kor-15-2-08 (VBGI); oil-bodies 3-6 per cell, filling cell lumen.

Plectocolea infusca var. ovicalyx (Steph.) Bakalin - wet cliffs along stream in broad-leaved forest mixed with conifers; 667-1437 m a.s.l.; 22 May 2008, SC 10549 (JNU), 30 Jun. 2008, SC 10878 (JNU).

Plectocolea rosulans (Steph.) S. Hatt. - ant.; wet cliffs and rocks along stream in broad-leaved and mixed forests; 625-998 m a.s.l.; 7 Jun. 2008, SC 10596 (JNU), 14 Apr. 2009, SC 13434 (JNU), 27 Jun. 2008, VB Kor-14-27-08 (VBGI), 30 Jun. 2008, VB Kor-16-20-08 (VBGI); oil-bodies 3-6 per midleaf cell, ovate.

Plectocolea virgata Mitt. - ant.; rocks along stream in broadleaved forest; 591-1584 m a.s.l.; 30 Oct. 2007, SC 10019 (JNU), 14 Apr. 2009, SC 13436 (JNU), 30 Jun. 2008, VB Kor-16-5-08 (VBGI); oil-bodies 2-6 per cell, granulate, mostly spherical, 7.5-10 × 5-7.5 $\mu \mathrm{m}$.

Plicanthus birmensis (Steph.) R. M. Schust - shaded cliffs in broad-leaved forest mixed with conifers and shrubs, rock outcrops in full sun; in pure mats or with Frullania tamarisci ssp. obscura, Herbertus dicranus; 1330-1580 m a.s.l.; 25 Jun. 2008, SC 10688 (JNU), 25 Jun. 2008, SC 10701 (JNU), 24 Jun. 2008, VB Kor-9-12-08 (VBGI), 25 Jun. 2008, VB Kor-10-8-08 (VBGI).

Plicanthus birtellus (F. Weber) R.M. Schust. - cliffs along stream in broad-leaved forest; $689 \mathrm{~m}$ a.s.l.; 1 Jul. 2008, SC 10962 (JNU).

Porella caespitans (Steph.) S. Hatt. - cliffs and rocks along stream in broad-leaved forest; $690-810 \mathrm{~m}$ a.s.l.; 30 Oct. 2007, SC 10022 (JNU), 14 Mar. 2009, SC 13407 (JNU), 30 Jun. 2008, VB Kor-16-1-08 (VBGI), 1 Jul. 2008, VB Kor-17-42-08 (VBGI).

Porella fauriei (Steph.) S. Hatt. - shaded stones and cliffs in broad-leaved and mixed forests; in pure mats or with Apometzgeria pubescens, Metzgeria furcata, Plagiocbila ovalifolia; 810-1400 m a.s.l.; 2 Apr. 2008, SC 10327 (JNU), 14 Apr. 2009, SC 13450 (JNU), 24 Jun. 2008, VB Kor-7-5-08 (VBGI), 30 Jun. 2008, VB Kor-16-16-08 (VBGI).

Porella gracillima Mitt. - only literature record (Hong 1966). 
Porella grandiloba Lindb. - shaded stone, wet cliffs and rocks along stream in broad-leaved and mixed forests; in pure mats or with Apometzgeria pubescens, Metzgeria conjugata; 690-1400 m a.s.l.; 28 Nov. 2007, SC 10049 (JNU), 14 Apr. 2009, SC 13454 (JNU), 24 Jun. 2008, VB Kor-7-1508 (VBGI), 1 Jul. 2008, VB Kor-17-50-08 (VBGI).

Porella japonica (Sande Lac.) Mitt. - shaded rocks along stream in broad-leaved forest; $680 \mathrm{~m}$ a.s.l.; 2 Apr. 2008, SC 10320 (JNU).

Porella oblongifolia S. Hatt. - cliffs along stream in broadleaved forest; 720 m a.s.l.; 27 Jun. 2008, SC 10843 (JNU), 27 Jun. 2008, VB Kor-14-22-08 (VBGI).

Porella ulophylla (Steph.) S. Hatt. - ant., per., spor.; cliffs along stream in broad-leaved forest; in pure mats or with Cephaloziella spinicaulis; $518-880 \mathrm{~m}$ a.s.l.; 28 Nov. 2007, SC 10043 (JNU), 5 Dec. 2008, SC 11208 (JNU), 1 Jul. 2008, VB Kor-17-25-08 (VBGI).

Porella vernicosa Lindb. - wet cliffs along streams in broadleaved and mixed forests; 690-1245 m a.s.l.; $28 \mathrm{Nov}$. 2007, SC 10054 (JNU), 14 Mar. 2009, SC 13404 (JNU), 26 Jun. 2008, VB Kor-11-7-08 (VBGI), 1 Jul. 2008, VB Kor-17-46-08 (VBGI).

Radula auriculata Steph. - wet cliffs along stream in broadleaved mixed forests; 720-1200 m a.s.l.; 26 Jun. 2008, SC 10744 (JNU), 30 Jun. 2008, SC 10875 (JNU), 26 Jun. 2008, VB Kor-11-14-08 (VBGI), 27 Jun. 2008, VB Kor14-16-08 (VBGI).

Radula cavifolia Hampe - shaded cliffs and rocks in Quercus forest; with Lejeunea ulicina, Cephaloziella spinigera; $1421 \mathrm{~m}$ a.s.l.; 30 Oct. 2008, SC11107 (JNU), 15 Apr. 2009, SC 13486 (JNU)

Radula constricta Steph. - shaded cliffs along stream and bark of trees in broad-leaved mixed forests; 576-1421 m a.s.l.; 12 Dec. 2007, SC 10192 (JNU), 15 Dec. 2008, SC 11191 (JNU).

Radula japonica Gott. ex Steph. - wet cliffs along stream in broad-leaved forest mixed with conifers, very wet and shady rocky wall in small grotto; in pure mats or with Blepharostoma trichophyllum, Conocephalum japonicum, Plagiochila trabeculata; 640-1200 m a.s.l.; 1 Dec. 2007, SC 10164 (JNU), 25 Jun. 2008, SC 10733 (JNU), 26 Jun. 2008, VB Kor-11-4-08 (VBGI), 27 Jun. 2008, VB Kor12-1-08 (VBGI).

Radula obtusiloba Steph. - shaded cliffs in broad-leaved forest mixed with conifers and shrubs; 590-880 m a.s.l.; 30 Oct. 2007, SC 10020 (JNU), 15 Dec. 2008, SC 11199 (JNU), 25 Jun. 2008, VB Kor-10-31-08 (VBGI).

Radula tokiensis Steph. - wet cliffs in broad-leaved forest; 828 m a.s.l.; 27 Apr. 2008, SC 10386 (JNU).

Reboulia hemisphaerica (L.) Raddi subsp. hemisphaerica - spor.; cliffs along stream in broad-leaved forest; $518-690 \mathrm{~m}$ a.s.l.; 28 Nov. 2007, SC 10045 (JUN), 1 Jul. 2008, SC 10947 (JNU), 1 Jul. 2008, VB Kor-17-44-08 (VBGI).

Riccardia multifida (L.) Gray var. decrescens (Steph.) Furuki wet cliffs along stream in broad-leaved forest; $1446 \mathrm{~m}$ a.s.l.; 14 Apr. 2009, SC 13448 (JNU).

Riccia buebeneriana Lindenb. - wet soil in cultivated field; 660 m a.s.l.; 22 Nov. 2008, SC 11169 (JNU), 22 Nov. 2008, SC 11176 (JNU).

Scapania ampliata Steph. - wet cliffs along streams in broadleaved and mixed forests; $1234-1444 \mathrm{~m}$ a.s.l.; 18 Sep. 2008, SC 11060 (JNU), 30 Oct. 2008, SC 11084 (JNU).

Scapania ciliata Lac. - per.; shaded cliffs along streams in broad-leaved and mixed forests; in pure mat or with Bazzania tricrenata, Cephaloziella sp.; $640-1330 \mathrm{~m}$ a.s.l.; 22 May 2008, SC 10494 (JNU), 14 Apr. 2009, SC 13466
(JNU), 25 Jun. 2008, VB Kor-10-12-08 (VBGI), 27 Jun. 2008, VB Kor-14-26-08 (VBGI).

Scapania integerrima Steph. - gemm.; shaded rocks and cliffs along streams in broad-leaved, mixed forests, and Alnus thickets; in pure mats or with Bazzania tricrenata, Marsupella emarginata var. tubulosa; 640-1330 m a.s.l.; 15 Apr. 2009, SC 13497 (JNU), 24 Jun. 2008, VB Kor-9-308 (VBGI), 1 Jul. 2008, VB Kor-17-16-08 (VBGI).

Scapania parvitexta Steph. - wet rocks along streams in broad-leaved forest; 625 m a.s.l.; 1 Jul. 2008, SC 10911 (JNU).

Scapania undulata (L.) Dumort. - arch.; wet cliffs along streams in broad-leaved and mixed forests; in pure mats or with Jamesoniella autumnalis, Marsupella pseudofunckii, Trichocoleopsis sacculata; 690-1200 m a.s.l.; 2 Apr. 2008, SC 10336 (JNU), 14 Apr. 2009, SC 13453 (JNU), 26 Jun. 2008, VB Kor-11-26-08 (VBGI), 1 Jul. 2008, VB Kor17-38-08 (VBGI).

Schistocbilopsis incisa (Schrad.) Konstant. - only literature record (Choe 1980).

Solenostoma emarginatum (Amakawa) Váňa, Hentschel \& J. Heinrichs - wet cliffs along stream in broad-leaved forest; 1060 m a.s.l.; 14 May 2009, SC 13593 (JNU).

Solenostoma pyriflorum Steph. - fine-grained soil along cliffs in Quercus forest; 1446 m a.s.l.; 5 Apr. 2009, SC 13477 (JNU), 5 Apr. 2009, SC 13481 (JNU).

Tetralophozia filiformis (Steph.) Urmi - cliffs along stream in broad-leaved forest; in pure mats or with Blepharostoma minus, Herbertus aduncus; $690 \mathrm{~m}$ a.s.l.; 1 Jul. 2008, SC 10958 (JNU), 1 Jul. 2008, SC 10981 (JNU), 1 Jul. 2008, VB Kor-17-35-08 (VBGI).

Trichocolea tomentella (Ehrh.) Dumort. - wet cliffs along streams in broad-leaved forests; $662 \mathrm{~m}$ a.s.l.; 27 Apr. 2008, SC 10420 (JNU).

Trichocoleopsis sacculata (Mitt.) S. Okamura - wet cliffs along streams in broad-leaved forests; in pure mats or with Jamesoniella autumnalis, Pedinophyllum truncatum, Plagiochila hakekodensis, Scapania undulata; 690-1200 m a.s.l.; 19 Mar. 2008, SC 10257 (JNU), 14 May 2009, SC 13589 (JNU), 26 Jun. 2008, VB Kor-11-13-08 (VBGI), 1 Jul. 2008, VB Kor-17-38-08 (VBGI).

Trocholejeunea sandvicensis Mizut. - per., ant., spor.; cliffs along stream in broad-leaved forest; $518-760 \mathrm{~m}$ a.s.l.; 28 Nov. 2007, SC 10092 (JNU), 22 Nov. 2008, SC 11136 (JNU), 1 Jul. 2008, VB Kor-17-29-08 (VBGI).

Xenochila integrifolia Inoue - shaded rocks and wet cliffs along streams in broad-leaved and mixed forests; in pure mats or with Jamesoniella autumanlis; 662-1245 m a.s.l.; 2 Apr. 2008, SC 10302 (JNU), 14 Apr. 2009, SC 13438 (JNU).

\section{ACKNOWLEDGEMENTS}

The authors express sincere thanks to Drs. C. H. Kim, M. O. Moon (JNU) and two anonymous reviewers for critical comments and suggestions. We are grateful to Dr. H. C. Lee (Korea National Park Service) for provided entry to Mt. Deogyu National Park. The work was supported by the grant "The Survey of Korean Indigenous Species" from the National Institute of Biological Resources of Ministry of Environment in Korea. Laboratory work of V. A. Bakalin was also supported by the Russian Foundation for Basic Researches (grants no. 12-04-91150, 13-04-00775). 


\section{LITERATURE CITED}

Amakawa, T. 1960. Family Jungermanniaceae of Japan. II. Journal of the Hattori Botanical Laboratory 22:1-90.

Ando, H. 1955. A revision of the taxonomic concept of Madotheca vernicosa (Lindb.) Steph. based upon a study of the variation. Journal of Science of the Hiroshima University, Series B. Division 2. 7:45-62.

Ando, H. 1960. Ecological notes on the Porella complex. Hikobia 2:45-62.

Bakalin, V. A., S. Choi \& B.-Y. Sun 2009. New national and regional bryophyte records, 20. : 25. Tetralophozia filiformis (Steph.) Urmi. Journal of Bryology 31:54-62.

Choe, D. M. 1980. Musci, Hepaticae. Illustrated flora and Fauna of Korea. 24. Seoul, 790 pp. (in Korean).

Gao, C. \& K. C. Chang 1981. Flora Hepaticarum Cbinae Boreali-Orientalis. Science Press, Pecking, 220 pp. (in Chinese).

Gao, C. \& K. C. Chang 1983a. A preliminary study on bryophytes of Changbai Mountain. Research of Forest Ecosystem 3:82-118 (in Chinese).

Gao, C. \& K. C. Chang 1983b. Bryophytes of North Korea. Miscellanea Bryologica et Lichenologica 9:163-170.

Gao, C. \& K. C. Chang 1983c. Bryophytes of North Korea. Bulletin of Botanical Research 3:118-131.

Hattori, S. 1943. Notulae de Hepaticae. VI. The Journal of Japanese Botany 19:345-356.

Hattori, S. 1947. Contributio ad Floram Hepaticarum Yakushimensem I. Journal of the Hattori Botanical Laboratory 1:1-26.

Hattori, S. 1952. Hepaticae of Shikoku and Kyushu, southern Japan (2). Journal of the Hattori Botanical Laboratory 7:21-46.

Hattori, S. 1956. Notulae de Hepaticae Japonicis (18). The Journal of Japanese Botany 31:201-204.

Hattori, S. 1978. Studies on the Asiatic species of the genus Porella (Hepaticae). VII. A synopsis of Asiatic Porellaceae. Journal of the Hattori Botanical Laboratory 44:91-120.

Hattori, S., W. S. Hong \& H. Inoue. 1962a. On a small collection of Hepaticae made on Querpart Island (Korea). Journal of the Hattori Botanical Laboratory 25:126-134.

Hattori, S., W. S. Hong \& H. Inoue. 1962b. A small collection of Hepaticae from the Chii Mountains (Korea). Journal of the Hattori Botanical Laboratory 25:279-286.

Hong, W. S. 1960a. Notes on Hepaticae of Mt. Setugakusan, Korea. Miscellanea Bryologica et Lichenologica 2:52.

Hong, W. S. 1960b. The flora of bryophytes on Mt. Kwanak, with some new additions to the Korean flora. Journal of Plant Biology 3:19-25.

Hong, W. S. 1960c. The bryophytes on Mt. Soyo, with some new additions to the Korean flora. Journal of Plant Biology 3:26-31.

Hong, W. S. 1966. The leafy Hepaticae of South Korea and their phytogeographic relationships, especially to the flora of North America. The Bryologist 69:393-426.

Hong, W. S. 1997. The Hepaticae and Athocerotae of Korean peninsula: annotated list of taxa. Lindbergia 22:134-142.

Hong, W. S. 2003. The Hepaticae and Athocerotae of Korean peninsula: identification keys to the taxa. Lindbergia 28:134-147.

Horikawa, Y. 1932. Studies on the Hepaticae of Japan. VII. Journal of Science of the Hiroshima University, Series B. Division 2. 1:121134.

Horikawa, Y. 1934. Symbolae florae Bryophytae Orientali Asiae. I. The Botanical Magagine Tokyo 48:452-462.

Horikawa, Y. 1955. Distributional Studies of bryophytes in Japan and the adjacent Regions, 27, 152 pp. Phytotaxonomical and Geobotanical Laboratory, Hiroshima University.

Inoue, H. 1958a. The family Plagiochilaceae of Japan and Formosa. I. Journal of the Hattori Botanical Laboratory 19:25-59.
Inoue, H. 1958b. The family Plagiochilaceae of Japan and Formosa. II. Journal of the Hattori Botanical Laboratory 20:54-106.

Inoue, H. 1959a. A review of Japanese species of Lophocolea Dum. Journal of the Hattori Botanical Laboratory 21:214-230.

Inoue, H. 1959b. On Metacalypogeia, a new genus of Hepaticae. Journal of the Hattori Botanical Laboratory 21:231-235.

Inoue, H. 1962. Two new species of Plagiochila Dum. The Journal of Japanese Botany 37:187-190.

Iwatsuki, Z. 2001. Mosses and Liverwort of Japan, 355 pp. Heibonsha, Tokyo (in Japanese).

Kim, Y. H. \& H. J. Hwang. 1991. Korean Spore Plant 8 (Hepaticae), 223 pp. Publiching House of Science on Encyclopodia, Pyongyang (in Korean).

Kim, Y. H., Y. R. Ri, H. D. Hoang, S. Huneck \& R. Grolle. 1995. Bryophytes and Lichens of Mt. Kumgang (DPR of Korea.). Feddes Repertorium 106:291-301.

Lai, M. J., K. W. Park, \& K. Choi. 2007. New Reports of Bryophytes from Korea. Journal National Taiwan Museum 60(1):6366.

Nakai, T. 1918. The Survey Report on Plants of Mt. Kumkang (Diamond), 204 pp. Seoul.

Park, K. W \& K. Choi. 2007. New list of Bryophytes in Korea, 150 pp. Korea National Arboretum, Korea Forest Service.

Reimers, H. 1931. Ein Beitrag zur Moosflora von Korea. Nova Hedwigia 70:359-372.

So, M. L. 2003.The genus Metzgeria (Hepaticae) in Asia. Journal of the Hattori Botanical Laboratory 94:159-177.

Song, J. S. \& K. Yamada. 2006. Hepaticae flora from Jeju (Cheju) Island, Korea. Journal of the Hattori Botanical Laboratory 100:443450.

Song, J. S. \& K. Yamada.2009a. Liverworts from Mt. Kaya (Gaya), South Korea. Journal of Phytogeography and Taxonomy 57(1):3538.

Song, J. S. \& K. Yamada.2006b. Liverworts of Mt. Jiri and its adjacent areas, South Korea. Natural Enviromental Science Research 22:15-21.

Stephani, F. 1909-1912. Species Hepaticarum IV, pp. 401-468. Georg et Cie, même Maison. Genève et Bâle, Lyon.

Stephani, F. 1912-1917. Species Hepaticarum V, pp. 987-988. Georg et Cie, même Maison. Genève et Bâle, Lyon.

Stephani, F. 1924 (1917-1924). Species Hepaticarum VI. Suppl. ad. Vol. I-V, pp. 8-471. Georg et Cie, même Maison. Genève et Bâle, Lyon.

Sun, B.-Y. \& J. H. Park. 1999. Flora on the mountain area of Mt. Deogyu (Mu-Ju, Geo-Chang), pp. 130-173. Ministry of Environment (in Korean).

Yamada, K. \& D. M. Choe. 1997. A checklist of Hepaticae and Anthocerotae in the Korean peninsula. Journal of the Hattori Botanical Laboratory 81:281-306.

Yamada, K. \& D. M. Choe. 2000. Two species of Frullania (Hepaticae) new to Korean pennisula. Bryological Research 7(9):285.

Yim, E.-Y. 2006. Bryophyte flora of Dongbaek-dongsan, Jeju-do, 79 pp. Master's thesis. Cheju National Univ, Cheju (in Korean).

Yim, K.-B., Y.-S. Kim, S.-H. Chun \& J.-I. Jeon. 1994. Floristic study on Tokyusan National Park. Korean Journal of Environment and Ecology 7:91-103 (in Korean).

Yoon, Y. J. 2009. Moss Flora on the mountain area of Mt. Deogyu in Korea, 281 pp. Master's thesis. Chonbuk National Univ., Chonbuk (in Korean).

Yu, Y. N. 2007. Flora on the mountain area of Mt. Deogyu, 30 pp. Master's thesis. Chonbuk National Univ., Chonbuk (in Korean). 